\title{
Uterine Corpus Cancer pTO TNM Finding v6
}

National Cancer Institute

\section{Source}

National Cancer Institute. Uterine Corpus Cancer pTO TNM Finding v6. NCI Thesaurus. Code C61340.

Uterine corpus cancer in which there is no evidence of a primary tumor. (from AJCC 6th Ed.) 